\title{
AMERICAN POLITICAL DISCOURSE: IRONY IN PRE-ELECTION CAMPAIGN 2016
}

\author{
Anna Gornostayeva \\ Moscow State Linguistic University \\ 38 Ostozhenka str., 119034, Moscow, Russia
}

\begin{abstract}
This article represents the analysis of American modern political discourse, mainly the field connected with the pre-election campaign 2016. It explores primary genres of political discourse (speeches, announcements, debates, party programmes), as well as secondary genres (commentaries, discussions, interpretation, political interviews). Owing to the fact that political communication embraces the whole range of informal political processes in society, the field of research includes the so-called informal political socializing. The aim of the paper is to study the use of irony and its functions in political discourse. The data used for the study were taken from candidates' speeches, interviews with political and public figures, and recent witty sayings/comments. The study is based on the theory of critical discourse analysis (M. Bilig 2007, Teun A. van Dijk 2009, N. Fairclough 1996, P. Graham 2007, J. Lemke 2007, S. Scollon 2007), political discourse analysis (A. Beard 2001, D. Ponton 2011 etc.) and theory of irony (L. Alba-Juez 2014, S. Attardo 2007, R. Giora 2001, 2003, L. Hutcheon 2005, B. Komlosi 2010 etc.). The analysis showed that irony is a frequent communicative strategy used by politicians in pre-election campaigns, it performs different functions, such as aggression, defense, entertainment and some others and plays a positive role in commucation with the audience. When used expertly, irony contributes to making political discourse more expressive and convincing. An ironic politician is a better manipulator of public opinion than one unable to use irony.
\end{abstract}

Key words: irony, politician, political genres, functions, mechanisms, linguistic means

\section{INTRODUCTION}

As the time of the presidential elections, 2016 in the USA is approaching, candidates and their pre-election campaigns attract increasing attention. As usual, there are obvious leaders who are very likely to be successful and those who take part in the event to gain popularity, or out of pure interest or for some other reason. In the Democratic Party, the highest position has always been held by Hilary Clinton (with the only serious rival Joe Biden, but he refused to take part in the election). The Republican party has been represented by many well-known figures, among whom are Jeb Bush, Mitt Romney, Ben Carson and, as it turned out during the election campaign, the most interesting and influential candidate - Donald Trump. The final battle is between the two charismatic and most articulate persons - Clinton and Trump whose influence upon an audience is great.

The aim of this study is to state the role of irony in the speeches of the candidates and draw a conclusion whether it helps them to create a positive image and achieve their goals. The material analysed proves that the use of irony by the speaker and its interpretation by the recipient do not depend on ideology or membership of the Republican or Democratic party. It rather depends on individual characteristics, the 
situation, and the cultural level. The candidates whose speeches are analyzed in this paper are the following:

Jeb Bush (uses irony quite sparingly);

Ben Carson (rare cases of irony, mainly to attack his opponent);

Bernie Sanders (occasional cases of irony);

The final contestants - Hilary Clinton (sticks to an official tone, practically no irony at all during the whole campaign, apart from Al Smith dinner) and Donald Trump (a really ironic speaker, bright examples of the use of irony). Mrs. Clinton is often criticized for not having a sense of humour and using ready-made jokes prepared by her speechwriters - as Donald Trump ironically remarks at Al Smith Memorial foundation dinner (October, 20, 2016):

I am sure Hilary is going to laugh quite a bit tonight, sometimes even at appropriate moments.

And:

You'll notice Hillary's not laughing. That's because she knows the jokes and all the jokes were given to her before the dinner by Donna Brazile ${ }^{1}$.

Mrs. Clinton wisely admits to not being as amusing as her opponent:

I am not known for my sense of humour... people say I am boring compared to Donald...

And adds ironically, saving her face and stressing her own positive sides:

...but I am not boring at all! In fact I am the life of every party I attend... and I have been to three. And when the parties get out of hand it is important to have someone responsible to get everyone home safe.

The main genres of political discourse which are involved in the current US preelection campaign are as follows: public speech, presidential debates, political interview and informal talk on political subjects which includes the exchange of opinions, parody, jokes about politics and politicians, discussions of political events in blogs (for example, the death of Margaret Thatcher caused the real battle between her fans and opponents in the Internet [Ponton 2011]). Thus, in this paper, I am going to analyze the speech of those running for presidency along with the comments of journalists and cultural figures which contain ironic comment. The material includes ironic remarks of political and cultural figures (current American president Barack Obama, former president Bill Clinton, senator Alan Greyson, actor Seth Meyers, actor Jimmy Fallon etc.), devoted to the candidates and their pre-election campaign.

\section{IRONY AND HUMOUR IN POLITICAL DISCOURSE, NOW AND THEN}

The role of humour and irony in political life as a means of attacking opponents was noted long ago and widely used by rhetors of ancient times (e.g. by Cicerone). A particular device known as Socratic irony (when one person pretends to be ignorant about an issue to lure the other person into explaining it) performs a defensive function and has been widely used in rhetoric up to the present day.

1 https://www.youtube.com/watch?v=Q0ryocAv8Zw. 
Some decades ago, reserchers defined political humour as "public property reworked and applied to new situations over and over again" [Schutz 1977: 25], with one of the main functions - discharging tension and relieving the situation: "For politicians: you can't simply deny the matter... the obvious alternative is humour... craft a joke or two about the issue... the issue will shrink in importance" [Lewis 2006].

Researchers of modern American political humour stress the two-pronged attitude to it in society. On the one hand, humour is considered a source of pleasure, an antidote to stress. On the other hand, humour can produce different effects: it may convey trustworthy or false information, cause love or hatred, reveal a problem or disguise it [Lewis 2006]. The situation has resulted in deep confrontation between the elaborate integration of humour in American political discourse and the opposite process - using it more sparingly to observe political correctness.

Some linguistic cultures (e.g. British, Greek, Italian) are characterized by a long tradition of using irony in political debates as a way of manifesting the eloquence of skillful speakers. Modern political discourse uses irony as well as other stylistic devices to ensure an influence on the audience and maintain its interest. Political discourse, highlighting events and facts from an ironic point of view, presupposes the active role of the audience; it gives up conventional views, as scientists state [Beard 2001]. The addressee turns into an active interpreter, rather than a passive information consumer.

Ideally, every politician should be a speaker and a writer, defending a definite platform. His/her language activity creates a certain image which may be more or less convincing for the audience. Rhetoric skills, the ability of weighing up words and ideas, formulating the style of social life via the style of speech have always been the tasks of any politician. As many researchers of critical discourse analysis state [Bilig 2007, Fairclough 1996, Gouveia 2007, Graham 2007, Lemke 2007, Scollon 2007, van Dijk 2009], there is a direct established relationship between society and discourse and while "being influenced by policy at the same time a politician "does" such policy" [van Dijk 2009: 86].

Political speech of a high quality should strike the right balance between a serious side and entertainment which presupposes inserting ironic comment, humour, anecdotes, and references to funny situations. The skillful use of irony contributes to political discourse and makes it more vivid and convincing, whereas an ironic speaker masters the art of manipulating public opinion far better than one devoid of irony.

\section{IRONY AS A LINGUISTIC PHENOMENON}

Irony is a notion viewed and understood widely from different points of view. Leaving out interpretations of irony as a philosophical and ethical category, I concentrate on its definitions from the point of view of the language:

"Irony - language which expresses a meaning other than that literary conveyed by the words, usually for humorous or dramatic effect”" [Cristal 1995: 170].

"Irony - the use of words to convey a meaning that is the opposite of its literal meaning: the irony of her reply, "How nice!" when I said I had to work all weekend" .

\footnotetext{
${ }^{2}$ http://dictionary.reference.com/browse/irony.
} 
"Irony - the use of words that mean the opposite of what you really think in order to be funny; a situation that is strange or funny because things happen in a way that seems to be the opposite of what you expected" 3.

"Irony: 1. a form of humour in which you use words to express the opposite of what the words really mean; 2. a strange, funny, or sad situation in which things happen in the opposite way to what you would expect" 4 .

"Irony - the expression of one's meaning by using language that normally signifies the opposite, typically for humorous or emphatic effect; a state of affairs or an event that seems deliberately contrary to what one expects and is often amusing as a result" ${ }^{\text {. }}$.

It can be derived from the definitions that the key words in most of them are opposite and contrary. Consequently, literally irony is associated with something not true. Indeed, as irony is connected with violation of contextual coherence and cultural norms and does not correspond to addressee's expectations [Attardo 2007], some scholars characterize it as insincerity and pretense.

This study regards irony from different angles - as an utterance, as a speech act, as a speech genre. All these notions are united by the sense they convey. An ironic utterance existing separately, without connection with the interlocutor's reaction cannot be considered a speech act. It is a text, containing irony as a stylistic device. Ironic speech act (both successful and unsuccessful) exists only in discourse, as a result of the speaker's and listener's collaboration. It cannot be fully realized without understanding on behalf of the addressee. Irony as a speech genre is more complicated and functions in the framework of a situation, event, text. It uses certain mechanisms and corresponds to the author's communicative intentions. Thus, the following definition of irony may be acceptable.

Irony is a speech genre which is based on language manipulation and presupposes the use of a word, expression or saying in a sense, different from its literal meaning. The function of irony corresponds to the communicative intention of the speaker; irony reflects people's mentality and has ethnic and cultural peculiarities.

Irony is viewed from different positions: there are theories supporting the speaker's position as well as those focusing on the listener which are based on a high degree of ironical speech creativity on the part of both participants - the addresser and the addressee [Hutcheon 2005]. Irony cannot realize its functions to the full if, owing to some reasons, the interlocutor fails to recognize and interpret it. So, irony is not always a ready-made tool - it is a form of cooperation between the addresser and the addressee. The interplay between speaker and listener should naturally be taken into account when analysing irony.

Much has been written about the negative modality of irony. Traditionally, this phenomenon is regarded as "inferred contradiction" [Alba-Huez 2014] with a disguised negative sense. However, irony can convey positive sense and is not necessarily connected with the meaning of the opposite. Linguists point out that irony is based not only on contradiction but also on hyperbole and litotes [Giora 2003]. There is a distinct connection between what is said and what is meant but these components are not identical

\footnotetext{
3 http://www.thefreedictionary.com/irony.

${ }^{4}$ MacMillan English Dictionary for Advanced Learners.

5 Oxford dictionary.
} 
and cannot replace each other. The pragmatic sense of the utterance should be clarified and amended by the context.

Sometimes, it is difficult to define whether irony is based on "contrary sense" because the word does not have it. B. Komlósi gives an example of non-existing contrary sense to the notion "white":

What a beautiful white wedding dress she has! Context: Contrary to the traditions and expectations (i.e. the bride's dress is white), the bride's dress is pink.

This example does not correspond to the common idea that irony is based either on the contrary meaning or exaggeration or understatement. A dress cannot be whiter or less white; there is no colour opposed to white. This phrase conveys an ironic sense based on a connection between what is said (What a beautiful white wedding dress she has) and what is meant (the wedding dress is pink, not white). The meaning, contrary to white is undefined; it may acquire different forms: white/not white, white/pink, white/black [Komlosi 2010]. The point is that in reality the dress is not white as the words claimed it to be. Therefore, listeners, applying Grice's truthfulness maxim, are forced to recognise this as ironic in order to account for the discrepancy between what their eyes tell them and what the speaker's words mean.

Other researchers support this idea and state that the functions of irony are much wider and emotions conveyed by it are far richer than just a negative attitude: "When a speaker is being ironical, he is not always trying to convey the opposite of the proposition or the literal meaning of the utterance; nor is he always echoing some previous utterance; nor is he always pretending. The ironic speaker may be doing all, some or none of these things and still be ironic" [Alba-Huez 1995: 14].

The idea of the functions of irony being wider and more variable than just a negative attitude can be proved by numerous examples of discourse. There is irony which has the function of hyperbole or understatement, as well as irony as a function of correction, rather than negation:

(1) The storm brought us a little rain today. (A camper describes nasty weather: irony as understatement.)

(2) The whale is not very thin. (A girl describes her friends: irony as understatement.)

(3) I am extremely popular. I am the God. (said by the guest star to the host of the show: self-irony as exaggeration.)

(4) I come from Bolton. Not from Michael Bolton. (said by the guest star to the host of a show: irony as correction.)

Success or absence of success in using irony in speech communication depends a lot on the skills of the speaker, propriety and ethics, but in general, the use of irony makes a welcome contribution. When it is necessary to lower tension and optimize interpersonal relations, irony is a useful tool. It is often used to avoid negative estimation, to soften critics and to defuse strong emotions: "...the author avoids being directly critical... this is construed as a matter of appreciation rather than judgement. Here the use of irony enables one to be positive rather than negative" [Martin, White 2005: 221].

Ironic utterances may be intended as well as unintended. If the author did not try to convey an ironic message but the addressee found one, this utterance contains unintended irony. R. Giora remarks: "An utterance is considered an unintended irony in 
case it is unintended literally but is perceived as ironic by overhearers. Intended ironies take longer to read than their unintended equivalents" [Giora 2003: 176] and gives an example of cheating at the exam as a context for an utterance which can be considered willingly or unwillingly ironic: "I would never be involved in any cheating". These are the words of a good student whose notes were copied by his badly-prepared friend who eventually got a good mark. The phrase is considered ironic no matter whether the first student was aware of his friend's cheating or not. Even if the phrase is devoid of irony, the addressee (who is well aware of the bad student's cheating) perceives it as ironic. As irony is a product of collaboration between the speaker and the listener, in this case it is the addressee whose interpretation contributes to the ironic effect. In any case, taking into consideration the inability of the bad student to pass the exam, the remark of the good student sounds ironic.

\section{FUNCTIONS AND MECHANISMS OF IRONY IN A POLITICAL CONTEXT}

The skill of inserting witty sayings in a political dialogue is an integral part of a successful politician's image. This analysis shows that ironic speakers are more efficient in influencing and manipulating an audience than those avoiding irony. Self-irony helps to prevent possible criticism or discourage opponents. Ironic statesmen know how to use this tool: "Politicians use jokes as a strategy aiming to embarrass their opponents in the eyes of other politicians. They joke to avoid discussions of pressing issues" [Fialkova, Yelenevskaya 2013: 218]. By contrast, those who stick to the official style are less popular. Obviously, to make an ironic speech popular, a lot of conditions should be fulfilled, such as the historical and cultural context, and the extralinguistic situation. The addressee should be aware of the present political and economic situation: "...in order to fully appreciate the meaning and significance of political humour one has to be familiar with the relevant political culture, the nature of disagreements and conflicts that are derided or condemned, and the goals of competing and struggling political forces" [Fialkova, Yelenevskaya 2013: 216].

Researchers single out a number of functions of irony, ranging from turning a dull political text into a vivid colourful one to self-expression of a political leader or political analyst. Irony and humour serve as an effective instrument during pre-election campaigns and as a channel to release tension and aggression: "When people need to relieve tension and pain, give vent to anger and reinforce the boundaries between in- and out-group members, they often resort to humour and ridicule" [Fialkova, Yelenevskaya 2013: 215-216]. It is possible to group all the enumerated functions of irony into three streams: attack, defence and entertainment.

As for the mechanisms of irony, the following ones can be singled out: paradox; breaking communicative expectations; ambiguity; an absurd conclusion; revealing the self-evident; denying the self-evident; a sudden change of style register et cetera. [Gornostaeva 2013: 172-190]).

\section{ATTACK}

Irony in its attacking function has a social character, and is directed to accentuating the faults of society and is similar to satire. It is meant to criticize and accuse. 
Debates in American parliament often contain sharp criticism. For example, in a debate in the House on health care reform in 2009, senator Alan Greyson uses irony while accusing the Republicans of being unfair:

They understand that if Barack Obama were somehow able to cure hunger in the world the Republicans would blame him for overpopulation. They understand that if Barack Obama could somehow bring about world peace they would blame him for destroying the defense industry ${ }^{6}$.

The phrase contains ironic paradox - the deliberate construction of illogical sequence which suggests a hidden sense (in this case, the speaker's negative attitude to the Republicans).

Ironic attacks often contain ambiguity which can only be understood by those familiar with the extralinguistic situation:

In an interview with Diane Sawyer, Hillary Clinton said she would make her decision on running for president 'by the end of the year.' Specifically, the year $1998^{7}$.

This phrase of an American actor and host of a TV show has bitter irony, referring to the period when ex-president Bill Clinton's adultery became widely known. According to Seth Meyers, it is the desire to take revenge on her disloyal husband that dominates Hilary Clinton's pre-election campaign. He thinks it was in 1998 when she took the decision to outperform him in politics because of jealousy which has influenced her all these years.

The mechanism of absurd conclusion is used in candidate Ben Carson's speech to attack his opponent:

If Hilary is the candidate, which I doubt... That would be a dream come true. She is taking advantage of useful idiots ${ }^{8}$.

The combination of a positive idea $a$ dream come true and a paradox useful idiots create an ironic effect. Mr. Carson proceeds his ironic attack, using an unusual tactics of giving advice on what to do to make things worse:

If I tried to destroy this country what I would do is trying to increase the national debt and step off the stage as a world leader and our enemies would increase while we decrease our capacities and that's what she is doing.

Criticizing an opponent becomes more effective if ironic ambiguity is involved. For example, speaking about Donald Trump, Hilary Clinton refers to his past involvement in estimating models at beauty contests:

People look at the Statue of Liberty and they see a proud symbol... a beacon of hope for people around the world. Donald looks at the Statue of Liberty and sees a four. Maybe a five if she loses the torch and tablet and changes her hair .

\footnotetext{
${ }^{6}$ 09.10.2009 http://yquotes.com/quotes/alan-grayson.

7 Seth Meyers, http://politicalhumor.about.com/od/hillaryclinton/fl/Hillary-Clinton-Jokes.htm.

8 YouTube. Dr. Ben Carson's Speech — 2016 First Republican Presidential Debate. 7.08.2015, Fox Channel.

${ }^{9} \mathrm{https}: / / \mathrm{www}$. youtube.com/watch? $\mathrm{v}=\mathrm{Q} 0 \mathrm{ryocAv} 8 \mathrm{Zw}$.
} 
Indeed, Trump's track record with women is notorious and comparing the Statue of Liberty to one of his girlfriends is truly ironic. Later in the same speech, Mrs. Clinton again used ambiguous hints and referred Trump's concern for her health:

Donald really is as healthy as a horse. You know, the one Vladimir Putin rides around on.

Here, she implicitly accuses Trump of being too loyal to Russia, and at the same time, uses a defensive function of irony which helps to avoid questions about her own health.

\section{DEFENCE}

Irony as a means of defence is a very productive tool in political debates. Here is a dialogue between two Republican candidates running for presidency — Donald Trump and Jeb Bush:

$\begin{array}{ll}\text { Interviewer. } & \text { Are you a puppet for your donors? } \\ \text { Bush. } & \text { Absolutely not. The only guy who wanted me to change my views and gave } \\ & \text { me money is Donald Trump. He wanted casino gambling in Florida. } \\ \text { Trump. } & \text { No. I promise - if I wanted it I would have got it. } \\ \text { Bush. } & \text { You got Hilary Clinton to come to your wedding because you gave her } \\ & \text { money. Maybe you work for Hilary Clinton... } \\ \text { Trump. } & \text { I am a businessman, I've got to get along with everybody. } \\ \text { Bush. } & \text { But the fact is... } \\ \text { Trump. } & \text { Excuse me... Jeb, for a second... } \\ \text { Bush. } & \text { No! } \\ \text { Trump. } & \text { More energy today, I like that }{ }^{10} .\end{array}$

While Jeb Bush conforms to an officially serious style, and accuses his opponent, Donald Trump feels at ease and discharges tension with the aid of irony (if I wanted it I would have got it, More energy today, I like that), which helps him sound superior and tolerant.

Sometimes, Trump's irony of defence turns into aggression, such as in the debate with Hilary Clinton:

Clinton. It is just awfully good that someone with the temperament of Donald Trump is not in charge of the law in our country.

Trump. Because you would be in jail ${ }^{11}$.

Mr. Trump uses ironic exaggeration, and speaks about imprisoning his opponent. It helps him to deny her accusations and turn the tables on her.

The strategy of defense is used by Jeb Bush at the end of his speech to avoid an awkward silence:

I will be a Commander-in-Chief to get back in the business of creating a more peaceful world... Please clap! ${ }^{12}$

10 YouTube. Donald Trump vs. Jeb Bush | Presidential Debate Highlights 16.09.2015.

${ }^{11}$ YouTube. Presidential Debate - DT: Bc you'd be in jail! - Hillary Clinton vs. Donald Trump 09.10.2016.

12 YouTube. Jeb Bush: "Please Clap...” 3.02.2016. 
Here, irony arises precisely from the disruption of a normal scheme: the audience applause follows their spontaneous approval of a performance. Asking for applause in its absence means not being successful, so the speaker tries irony in a defence function, and saves his face.

During political interviews, politicians are bombarded by tricky questions and often irony is the only way to react and save their face:

Interviewer. When it comes to foreign policy you say there is a lot to learn. You admit that you have to study up. You said that The Baltic States are not a part of the NATO. You are unfamiliar with the major political parties in Israel and domestically you thought that Alan Greenspan had been a treasury secretary instead of Federal reserve chair. Aren't these basic mistakes? And don't they raise a legitimate question about whether you are ready to be a president?

Ben Carson. The most important thing is to have brain... ${ }^{13}$

Here, the candidate uses the mechanism of revealing the obvious: it is evident that every person has a brain and there are many more other conditions to be fulfilled in order to become the head of state. Rather than denying accusations or justifying himself, he focuses on the positive side. Eventually, it helped him to avoid a direct answer.

Another important function of irony is relieving tension at dangerous moments when a heated debate is likely to turn into a fight. The skill to defuse arguments and stop confrontation with a joke is an important ability of a wise leader. Press conferences can be especially thrilling for the ready-made remarks and questions of journalists, and may catch a politician off his guard. Irony, used at the right time and on purpose, contributes to the positive image of the speaker. Sometimes, irony is not only desirable, but necessary, like in the case of Bill Clinton's remark about his wife: $\operatorname{less}^{14}$.

She's having a little fun being a private citizen. Not Bill Clinton fun, but fun nonethe-

Everybody understands the hidden sense in former president's words and what "fun" he refers to, and it seems the only way to preserve dignity — to speak openly about some unpleasant events.

This strategy is used by Donald Trump at Al Smith dinner (October, 20, 2016), when he deliberately raises an unpleasant issue and makes fun of it:

The press this year is more biased than ever. You want an example? Michelle Obama gives a speech and everyone loves it, it's fantastic. They think she's absolutely great. My wife, Melania, gives the same exact speech and people get on her case and I don't get it! ${ }^{15}$

This ironic response to allegations of plagiarism levelled at his wife's Convention speech should stop all criticism for ever.

The current US president Barack Obama employs the same strategy. Here is his selfirony in response to accusations from the Republicans:

I've been called worse on the basketball court ${ }^{16}$.

13 YouTube. Dr. Ben Carson's Speech - 2016 First Republican Presidential Debate. 7.08.2015 Fox News Channel.

${ }^{14} \mathrm{http} / / /$ politicalhumor.about.com/od/hillaryclinton/fl/Hillary-Clinton-Jokes.htm.

$15 \mathrm{https} / / / \mathrm{www}$.youtube.com/watch?v=Q0ryocAv8Zw. 
And a phrase prepared in advance for the speech in Westminster abbey:

In this hall people who spoke were the Pope, her Majesty the Queen, Nelson Mandela, and now me... which is either a very high bar or the beginning of a very funny job ${ }^{17}$.

Comparing himself to other famous people, Obama deliberately diminishes his role, using irony in a preventive function.

Politicians are ironic about themselves in pre-election speeches, speaking about personal traits, appearance or, for example, age:

When I was a little boy my father used to love coming here. It's a long time ago... I won't say how many years because I love to think I am a young man $^{18}$.

In the same speech, Trump uses ironic exaggeration to stress his popularity among women:

Nobody could be better or do better for women than Donald Trump. I'd rather do well with women than with men. With men I am doing great - I am just killing everybody. With women... they are not so terrible but they could do better.

The mechanism of irony violates communicative expectations: instead of stressing such traits as generosity, a concern about the electorate, Trump shocks the public with uncommon announcements in a political context: I am just killing everybody, women are not so terrible. It makes his speech informal and narrows the distance between the speaker and the audience.

\section{ENTERTAINMENT}

Entertainment is one of the main functions of irony in modern political discourse. Linguists even suggest the new term - "infotainment" which means "information + entertainment" [Fialkova, Yelenevskaya 2013], becoming more and more popular today when the public craves for fun and sensation rather than political news. One of the ways to create "infotainment" is irony.

The coming presidential election poses a vast field for irony, sarcasm, and witty remarks. Journalists and observers never miss a chance to exploit the topic:

Hillary Clinton is now in Iowa. She's spending every waking minute of her day meeting ordinary people, and it's to prepare her for a job in which she will never again meet an ordinary person (David Letterman).

Bill Clinton was being interviewed recently, and he said that despite all the speculation, Hillary hasn't said anything to him about running for president in 2016. Though in fairness, she hasn't said anything to him since 1998 (Jimmy Fallon).

Republicans are already trying to paint Hillary Clinton as too old to be president. In fact, a new ad claims she's so old that she could be a Republican (Conan O'Brien).

This week in New Orleans, Hillary Clinton said she still doesn't know if she's running for president in 2016. Isn't that unbelievable? With 315 million Americans, what

${ }^{16} \mathrm{http}: / / \mathrm{www}$. allgreatquotes.com/barack_obama_funny_quotes.shtm.

17 YouTube. President Obama Addresses the British Parliament, 25.05.11.

18 YouTube. Presidential Election 2016: Donald Trump in Miami FULL Speech HD 3.02.2016. 
are the odds she's the only one in the country who doesn't know she's running for president in 2016? (Jay Leno) ${ }^{19}$.

Jeb Bush may run for President. Bush Presidencies are like 'Caddyshack' movies. They should have stopped with one (David Letterman).

Jeb announced on the Internet that he is exploring a 2016 bid for president. And to increase his chances, he's going to run as just 'Jeb.' He said, 'My last name? It's not important (Seth Meyers) ${ }^{20}$.

Such informal talks about political events are popular with an audience and play a big role in either supporting a candidate's image or ruining it. Irony in these phrases is mostly based upon ambiguity, and is clear for those who are aware of the circumstances. The addressee is supposed to know certain facts about the Bushes and the Clintons. Other candidates are less often the laughing stock. The general trend is: the more popular the statesman, the bitterer the irony. Still, there are some witty sayings about less successful candidates (they are often mentioned in opposition to Hilary Clinton):

Mitt Romney we think is going to run again. He says he has no plans to run, but he said if he did run, this time things would turn out differently. Yes they would. This time he would get his ass kicked by a woman (Bill Marr).

Joe Biden said that Hillary Clinton's decision to run for president won't affect his decision to launch a campaign. While Hillary says Biden's decision to run for president won't affect her becoming president (Jimmy Fallon).

A New York Times poll says that eight out of ten Democrats want Hillary Clinton to run for president in 2016. The same poll also shows that ten out of ten Democrats want Chris Christie to run against her (Seth Meyers).

Joe Biden said this week that he still dreams of being president. To which Hillary said, 'Keep dreaming' (Jay Leno) ${ }^{21}$.

It is clearly seen that Mrs. Clinton as the leader is an object of irony, while her rivals are far less interesting for journalists' and analysts' bitter remarks. It is unlikely to be her platform or ideology that attracts so much attention; rather it seems to be her character, her lack of humour, and some facts from personal life.

Clinton's main opponent, Mr. Trump, is known to laugh at himself (and at the whole race for presidency), and probably this feature spares him bitter remarks from others. Here are some of his phrases after the heated debates are over:

I'm a modest person, in fact, many people tell me that modesty is perhaps my best quality. Even better than my temperament.

We can be civil to each other. Hillary accidentally bumped into me and she very civilly said, 'Pardon me', and I very politely replied, 'Let me talk to you about that after I get into office'.

19 http://politicalhumor.about.com/od/hillaryclinton/fl/Hillary-Clinton-Jokes.htm.

${ }^{20} \mathrm{http}: / /$ politicalhumor.about.com/od/2016-Election/fl/2016-Election-Jokes.htm.

${ }^{21}$ http://politicalhumor.about.com/od/2016-Election/f1/2016-Election-Jokes.htm. 
If by any chance she gets elected she wants me to be either her ambassador to Iraq or Afghanistan. It's my choice ${ }^{22}$.

Trump's self-irony, his readiness to make a witty remark defend him from a lot of criticism and make him a charismatic political figure.

\section{MEANS OF EXPRESSING IRONY}

Irony poses great challenges for creativity and variety - including the ways of expressing it. Ironic utterances are based on metaphors, hyperbole, litotes, comparison, quotation, and word play et cetera. This paper concentrates on language means only, and disregards non-verbal ways (widely practiced by the so-called "third American party" Libertarians) $)^{23}$.

Metaphors are one of the favourite ways of expressing irony. The most interesting ones are newly composed words based on well-known expressions. For example, Barack Obama speaks about the attitude of his opponents to himself:

My campaign is criticized because I talk about hope too much: "he is so naïve... he is idealist. His head is in the clouds, he is a hopemonger... he is peddling false hopes "24.

The new word hopemonger (antonym to warmonger) stuck to the current president in 2007. Obama deliberately stresses his nickname with a great deal of self-irony.

Some ironic metaphors can sound quite offensive:

Mitt Romney said he is considering a third presidential bid. Romney said he got the idea from watching his dog repeatedly run into an electric fence (Seth Meyers) ${ }^{25}$.

A similarity between a candidate for presidency and a stupid animal is not pleasant. The same is true about the following remark characterising Joe Biden and made by president Obama:

He is warm, he is cuddly, loyal, enthusiastic; you just have to keep him on a tight leash - every once in a while he goes charging off and gets himself into trouble. Enough about Joe Biden ${ }^{26}$.

Despite positive attributes, the general attitude is indulgent and superior which is emphasised by the metaphor to keep on a tight leash, which is associated with dogs. The irony seems to derive from the application of animal characteristics to something that is not an animal.

${ }^{22} \mathrm{https}: / / \mathrm{www}$. youtube.com/watch?v=Q0ryocAv8Zw.

23 The Libertarians use funny and tricky ways of capturing attention of the audience, like the striptease performed by James Weeds at Libertarian Party Convention, Orlando, 30th of May 2016. Wearing boots on their heads, transparent raincoats with no underwear, dressing like Batman, Superhero or Harry Porter are also ways of expressing their own position and ironic attitude to politics in general used by some party members.

24 YouTube. Barack Obama Best speech ever, 19.09.13.

${ }^{25} \mathrm{http}: / /$ politicalhumor.about.com/od/2016-Election/fl/2016-Election-Jokes.htm.

${ }^{26}$ President Barack Obama, at the 2009 White House Correspondents' Dinner. 
Another metaphor refers to the strong character of Hilary Clinton:

Scandals don't weaken Hillary Clinton, they only make her stronger. Hillary Clinton eats scandals for breakfast (Bill Maher) ${ }^{27}$.

Hyperbole is another productive way of expressing irony. To stress the role of his party in the political arena, the Libertarian leader Gary Johnson uses exaggeration and ironic paradox:

I think the majority of people in this country are libertarians, but they don't know about $i^{28}$.

Donald Trump ironically exaggerates the role of money in pre-election campaign:

When you are going to be Number 1 everybody is willing to give you money. It's incredible ${ }^{\text {!9 }}$

Hilary Clinton, speaking about her husband and the advantages of the Democrats, uses quotation:

When my husband was asked: "What did you uniquely bring to Washington?" — he answered: "Arithmetic" 30 .

In this phrase irony functions as a violation of communicative expectations - instead of naming something significant, great and pompous, the answer is simple and unambitious.

Ironic comparisons create vivid images which stick in people's minds:

Being president is like running a cemetery: you've got a lot of people under you and nobody's listening (Bill Clinton) ${ }^{31}$.

Or:

Some of the candidates... they didn't know the air conditioning didn't work. They sweated like dogs... how are they going to be nicest ${ }^{32}$

Mr. Trump's speech is full of bright comparisons. For example, he speaks about restoring Miami Hall and draws parallel to reviving the country:

About reconstruction:

This room new... We have five ball rooms We have 700 rooms we have golf courses... A man came up to me and said: Mr. Trump it is a tremendous place... it is a really successful place! If you could do the same for the US that would be unbelievable! And you know: doing it for the US might be easier to do than doing this job here ${ }^{33}$.

Here, Mr.Trump may be quite serious and non-ironic, but listeners can perceive his words as full of irony, as common sense says that the whole country is certainly bigger and harder to reconstruct than one building.

${ }^{27} \mathrm{http} / / /$ politicalhumor.about.com/od/hillaryclinton/f1/Hillary-Clinton-Jokes.htm.

${ }^{28}$ YouTube 01.06.2016. The party crashes: meet the Libertarians.

${ }^{29}$ YouTube 3.02.2016 Presidential Election 2016: Donald Trump in Miami FULL Speech HD.

$3022.12 .15 \mathrm{http}: / /$ hillaryspeeches.com.

${ }^{31} \mathrm{http}: / /$ quotes.lifehack.org/quote.

32 YouTube. Donald Trump Presidential Announcement Full Speech 6.16.15.

33 YouTube. Donald Trump Presidential Announcement Full Speech 6.16.15. 
Finally, word play is a very efficient tool of irony. Here are some examples. Introducing her father to the audience, Ivanka Trump says:

My father is the opposite of politically correct: he says what he means and he means what he says ${ }^{34}$.

Ironic paradox here is built on parallel constructions and the new positive sense of "the opposite of politically correct". The intended meaning is to describe Trump as a sincere, straightforward person, not a hypocrite. Ms. Trump continues:

When it comes to building bridges, he can do so figuratively but also has the rare ability to do so literally on time and under budget.

The set expression to build bridges is used in one sentence in both meanings literal and figurative.

The same strategy is applied by Bernie Sanders, expressing the desire to beat Donald Trump - figuratively, of course, during the presidential race. However, the literal meaning of the verb is still present in his ironical tone:

— Do you focus on beating Donald Trump or Hilary Clinton?

— I am looking forward to beating Donald Trump. I will enjoy this race. And with secretary Clinton... I think we will do it as well ${ }^{35}$.

Irony here arises from the extra linguistic situation (Mr. Sanders would eagerly give Mr. Trump a good beating if he could). Saying that he is looking forward to beating Donald Trump, he means both senses of the verb to beat, so irony is based on word play.

\section{DISCUSSION}

As can be seen from the examples above, modern political discourse is full of ironic remarks. Irony in the US pre-election campaign is used by those running for presidency in formal and informal speeches as well as those who afterwards comment on the situation. Irony plays an essential part in debates in order to belittle opponents and seem superior, to persuade the audience, to save your face in an awkward situation, and to avoid answering tricky questions. At the same time, irony helps to hold the attention of an audience, to accentuate important points, and to contribute to the positive image of the speaker. Thus, all these three functions - attack, defence and entertainment - cooperate to achieve the ultimate goal of political discourse - to gain power.

It has been noticed that those political figures who lack a sense of humour and take themselves too seriously invite a lot of jokes and bitter remarks from observers of the political scene. By contrast, fun-loving politicians, who master irony and selfirony receive fewer negative reviews and are rarely made fun of. Ironic utterances are a way to prevent criticism, to bring an undesirable issue to a quick end, or switch to a new topic.

Different mechanisms of irony are often combined to produce the necessary effect. In the examples above, the most effective ones are paradox, ambiguity, absurd conclu-

${ }^{34}$ YouTube. Donald Trump Presidential Announcement Full Speech 6.16.15.

35 YouTube. 9.12.15. Bernie Sanders Looks Forward to Beating Donald Trump. 
sion, and revealing the self-evident. The boundaries between the mechanisms are not always distinct: in combination, they serve the same aim. Speakers use irony in the form of metaphors, ironic comparisons, hyperbole, and word play et cetera. All these means serve to make a speech bright, memorable and appealing to an audience.

\section{CONCLUSIONS}

1. Political discourse is a form of communication which presupposes an active role of the audience, and turns the addressee into a concerned interpreter. Given the current trend of combining information with fun, modern political speech of high quality should strike the right balance between a serious side and entertainment. The attitude to irony and humour in modern American political discourse is different, but practice shows that skillfully used irony contributes to the effect of a speech, helps to achieve a communicative function and increases the speaker's influence on an audience.

2. A skillful speaker strikes the right balance between a serious message and fun. Ironic comments help to relieve tension, attract attention to certain points and, ultimately, contribute to the positive image of a politician. Public attitude shows that ironic speakers are more popular and more successful than those who only maintain an official style. Thus, irony is an important and integral part of modern political discourse.

3. The material analysed shows that irony is used by all candidates in the presidential race (at different frequency and in various functions). Even those who tend to stick to the official style and be reserved in their speech (e.g. Hilary Clinton) use irony in order to draw attention to certain facts, and to entertain an audience. Bernie Sanders disguises (and at the same time, accentuates) his negative attitude to the opponents by means of irony. This device helps Ben Carson to attack opponents, save his own face and avoid unwelcome questions, Jeb Bush - uses the same to fill in awkward silence at the end of his speech. The candidate who applies irony most often is Donald Trump and, therefore, may be defined as an ironic speaker since irony is an inherent trait in his style of speech. This politician employs ironic comments to his opponents in order to criticize and, in the long run, outperform them; he also uses self-irony to prevent attacks or ease tension. In reality, most of his ironic phrases are a part of his show, and are meant to amuse and please his audience.

It is still a debatable question whether irony helps to win an election campaign, but it certainly contributes to the image of the speaker and influences an audience.

It may be noted that ironic remarks as comments on election campaign are mostly about Mrs. Clinton, and include hints on her family situation and her past (made by Bill Marr, Jay Leno, Seth Meyers etc). Jeb Bush, being a member of a famous family, also attracts many ironic remarks by such show-men such as David Letterman, Jay Leno et cetera. Other candidates deserved less attention from observers.

(C) Anna Gornostayeva, 2016

\section{REFERENCES}

Alba-Juez L. (1995) Irony and the other off record strategies within politeness theory. Miscelanea $16,13-23$. 
Alba-Juez L. (2014) Irony as inferred contradiction // Russian Journal of Linguistics 4, 139-152.

Attardo S. (2007) Irony as a Relevant Inappropriateness // Irony in Language and Thought. A Cognitive Science Reader. Ed. by H.L. Colston and R.W. Gibbs. New York, London: Lawrence Erlbaum Associates, 135-172.

Beard A. (2001) The language of politics. Taylor \& Francis e-Library.

Billig M. (2007) Critical Discourse Analysis and the Rhetoric of Critique // Critical Discourse Analysis. Theory and Interdisciplinarity. Palgrave Macmillan, 35-47.

Crystal D. (1995) The Cambridge Encyclopedia of the English Language / D. Crystal. Cambridge: CUP.

Fairclough N. (1996) Language and power. Longman.

Fialkova L., Yelenevskaya M. (2013) In Search of the Self: Reconciling the Past and the present in Immigrants' Experience. Tartu ELM Scholarly Press.

Gornostaeva A.A. (2013) Irony as a component of the English communication style. [Ironia kak component angliiskogo stilya kommunikatsii]. Moscow, Maska. 240 p. [in Russian].

Giora R. (2001) Irony and its discontent // Utrecht publications in general and comparative literature. Vol. 35. John Benjamins publishing company. Amsterdam, Philadelphia, 165-185.

Giora R. (2003) On our mind: Salience, context, and figurative language. New York: Oxford University Press.

Graham P. (2007) Critical Discourse Analysis and Evaluative Meaning: Interdisciplinarity as a Critical Turn // Critical Discourse Analysis: Theory and Interdisciplinarity. Palgrave Macmillan, $110-130$.

Gouveia Carlos A.M. (2007) Critical Discourse Analysis and the Development of the New Science // Critical Discourse Analysis: Theory and Interdisciplinarity. Palgrave. Macmillan, 47-63.

Hutcheon L. (2005) Irony's Edge. The Theory and Politics of Irony / L. Hutcheon. New York: Routledge.

Komlósi B. (2010) Irony in the semantics-pragmatics interface: A reconstructional model. November 11. [http://www.eotvos.u-szeged.hu/ vozparag/komlosi_irony.pdf].

Lemke J. (2007) Texts and Discourses in the Technologies of Social Organization // Critical Discourse Analysis: Theory and Interdisciplinarity. Palgrave Macmillan, 130-150.

Lewis P. (2006) Cracking up: American humour in a time of conflict. The University of Chicago Press.

Martin J.R., White P.R.R. (2005) The Language of Evaluation. Appraisal in English. Palgrave Macmillan New York, N.Y. 278 p.

Ponton D.M. (2011) For Arguments' sake: speaker evaluation in modern political discourse. Cambridge Scholars Publishing. $110 \mathrm{p}$.

Schutz C.E. (1977) Political humour from Aristophanes to San Ervin. Assossiated University presses, London 1977.

[https://books.google.com.tr/books?id=Q7i40PY6AzgC\&printsec $=$ frontcover\&hl=tr\&source $=$ gbs ge_summary_r\&cad $=0 \# \mathrm{v}=$ onepage $\& \mathrm{q} \& \mathrm{f}=$ false].

Scollon S. (2007) Political and Somatic Alignment: Habitus, Ideology and Social Practice // Critical Discourse Analysis: Theory and Interdisciplinarity. Palgrave Macmillan, 167-199.

Van Dijk Teun A. (2009) Society and discourse: how social contexts influence text and talk. Cambridge University Press, 2009. 299 p.

\section{Article history:}

Received: 20 October 2016

Revised: 21 November 2016

Accepted: 29 November 2016 


\author{
For citation: \\ Gornostayeva, A. (2016). American Political Discourse: Irony in Pre-Election Campaign 2016. \\ Russian Journal of Linguistics, 20 (4), 179-196.
}

\title{
Bio Note:
}

Anna Gornostayeva, PhD, Associate Professor of The General Translation Department, Faculty of Intercultural Communication at Moscow State Linguistic University. Research Interests: discourse analysis, political discourse, intercultural communication, pragmatics, translation and interpreting. Contact information: e-mail: anngornostaeva@yandex.ru

\section{АМЕРИКАНСКИЙ ПОЛИТИЧЕСКИЙ ДИСКУРС: ИРОНИЯ В ПРЕДВЫБОРНОЙ КАМПАНИИ 2016 г.}

\author{
А.А. Горностаева \\ Московский государственный лингвистический университет \\ 119034 Россия, ул. Остоженка, д. 38
}

Статья представляет собой анализ современного политического дискурса США, а именно той области, которая связана с предвыборной кампанией кандидатов в президенты на выборах 2016 г. Рассмотрены как первичные речевые жанры (речи, заявления, дебаты, партийные программы), так и вторичные (комментирование, обсуждение, интерпретация, политические интервью). Поскольку политическая коммуникация подразумевает весь диапазон неформальных политических процессов в обществе, в сферу исследования вошло так называемое неформальное политическое общение. Цель статьи - показать роль иронии в американском политическом дискурсе и выделить ее функции. Приводится подробный анализ механизмов и языковых средств выражения иронии. В качестве анализируемого материала использовались отрывки из предвыборных речей кандидатов на пост президента, интервью с политическими и общественными деятелями США, а также современные афоризмы известных лиц. Методологической основой статьи послужили работы по критическому анализу дискурса (M. Bilig 2007, Teun A. van Dijk 2009, N. Fairclough 1996, P. Graham 2007, J. Lemke 2007, S. Scollon 2007), анализу политического дискурса (A. Beard 2001, D. Ponton 2011 и др.), работы, представляющие различные подходы к осмыслению иронии (L. Alba-Juez 2014, S. Attardo 2007, R. Giora 2001, 2003, L. Hutcheon 2005, B. Komlosi 2010, и т.д.). Статья содержит выводы о том, что ирония является одной из наиболее распространенных стратегий, используемых в предвыборных выступлениях кандидатов, она выполняет разные функции, среди которых нападение, защита, развлечение и др., она может играть положительную роль во взаимодействии с аудиторией - умело использованная ирония делает политический дискурс более ярким, экспрессивным и убедительным, а ироничный политик владеет искусством манипулирования общественным мнением лучше, чем оратор, обходящийся без иронии.

Ключевые слова: ирония, политик, политический жанр, функции, механизмы, языковые средства

\section{История статьи:}

Дата поступления в редакцию: 20 октября 2016

Дата принятия к печати: 29 ноября 2016 


\section{Для цитирования:}

Gornostayeva A. American Political Discourse: Irony in Pre-Election Campaign 2016 // Вестник Российского университета дружбб народов. Серия: Лингвистика. 2016. Т. 20. № 4. C. 179-196.

\section{Сведения об авторах:}

Горностаева Анна Александровна, кандидат филологических наук, доцент кафедры общего переводоведения, факультет межкультурной коммуникации, Московский государственный лингвистический университет. Сфера научных интересов: анализ дискурса, политический дискурс, прагматика, межкультурная коммуникация, перевод и переводоведение. Контактная информация: e-mail:anngornostaeva@yandex.ru 